\title{
PENGARUH SISTEM AKUNTANSI KEUANGAN DAERAH TERHADAP AKUNTABILITAS KEUANGAN DAERAH: KUALITAS LAPORAN KEUANGAN SEBAGAI VARIABEL INTERVENING
}

\author{
Oleh: \\ Agus Widarsono \\ (Dosen Program Studi Akuntansi Fakultas Pendidikan Ekonomi \& Bisnis UPI) \\ Ela Laelatul Fuadiyyah \\ (Alumni Program Studi Akuntansi Fakultas Pendidikan Ekonomi \& Bisnis UPI)
}

\begin{abstract}
In order to run the financial accountability to the public, local governments must design and run the accounting system properly, so that it would guarantee the principle of stewardship and accountability well too. Implementation of financial accounting systems for local government can present a good area of local government financial statements with appropriate information (relevance), complete and reliable (accurate) so that the qualitative characteristics of financial statements can be filled. The purpose of this study is to determine the magnitude of the effect of financial accounting system for local government towards financial accountability for local government with financial report quality as intervening variable. The research method used is causal design. Populations as well as samples in this study consist of the agency Satuan Kerja Pengelola Keuangan Daerah (SKPKD) and Local Government Inspectorate in 10 districts $/$ municipalities in Region IV of West Java Province. Statistical analysis used was Path Analysis with the $F$ test for testing the indirect effect and the $t$ test for testing the direct effect with the significance level of 5\%. The collected-data then was analyzed with SPSS version 13. As for the result of testing the direct influence of financial accounting system for local government towards financial accountability for local government is equal to 18.4\%. Whereas, as for the results of testing the influence of the financial accounting system for local government towards financial accountability for local government with financial report quality as intervening variable that there is a contribution of the results obtained from the financial accounting system for local government with financial accountability for local government statements as intervening variable is equal to $31.7 \%$, while the remaining balance of $68.3 \%$ is the influence of other factors beyond the two variables.
\end{abstract}

Keywords: Financial Report Quality, Financial Accounting System For Local Government, Financial Accountability For Local Government.

\section{Latar Belakang}

Reformasi keuangan daerah yang diawali dengan bergulirnya UU Nomor 22 Tahun 1999 yang kemudian diubah menjadi UU Nomor 32 Tahun 2004 tentang Pemerintahan Daerah dan UU Nomor 25 Tahun 1999 diubah menjadi UU Nomor 33 Tahun 2004 tentang Perimbangan Keuangan Pemerintah Pusat dan Daerah, dan aturan pelaksanaannya, khususnya PP Nomor 105 tahun 2000 tentang Pengelolaan dan Pertanggungjawaban Keuangan Daerah maka terhitung tahun anggaran 2001 , telah terjadi pembaharuan di dalam manajemen keuangan daerah. Dengan adanya otonomi ini, daerah diberikan kewenangan yang luas untuk mengurus rumah tangganya sendiri dengan sesedikit mungkin campur tangan pemerintah pusat.

Dalam perkembangannya, era reformasi dan otonomi daerah telah ikut mempengaruhi perubahan paradigma pengelolaan maupun pelaporan keuangan daerah secara signifikan. Pemerintah daerah sekarang mendapat amanat untuk mengelola dana publik dengan tujuan meningkatkan kesejahteraan masyarakat daerah dalam berbagai bidang atau urusan. Amanat tersebut tercantum dalam Undang-undang Keuangan Negara Nomor 17 tahun 2003 pasal 3, Undang-undang Perbendaharaan Negara Nomor 1 Tahun 2004, Undang-undang Nomor 32 Tahun 2004 tentang Pemerintahan Daerah, serta Undang-undang Nomor 33 Tahun 2004 tentang 
Perimbangan Keuangan Antara Pemerintah Pusat dan Pemerintahan Daerah. Sebelum masa otonomi, aturan pemerintah daerah membuat laporan keuangan tidak seketat sekarang. Pengelolaan keuangan daerah saat ini tidak saja harus mengalokasikan dana publik bagi kepentingan kesejahteraan masyarakat daerah, tetapi juga harus mengelola dana publik tersebut sesuai dengan Undang-Undang dan aturan yang dikeluarkan pemerintah pusat. Kepatuhan terhadap Undang-Undang dan aturan dalam pengelolaan keuangan daerah diperiksa institusi pemeriksa internal daerah (Inspektorat) maupun pemeriksa eksternal (BPK).

Sebelum bergulirnya otonomi daerah, pertanggungjawaban laporan keuangan daerah yang harus disiapkan oleh Pemerintah Daerah hanya berupa Laporan Perhitungan Anggaran dan Nota Perhitungan dan sistem yang digunakan untuk menghasilkan laporan tersebut adalah MAKUDA (Manual Administrasi Keuangan Daerah) yang diberlakukan sejak tahun 1981. Pada tanggal 10 Juni 2002 ditetapkan Keputusan Menteri Dalam Negeri Nomor 29 Tahun 2002 tentang Pedoman Pengurusan, Pertanggungjawaban dan Pengawasan Keuangan Daerah serta Tata Cara Penyusunan Anggaran Pendapatan dan Belanja Daerah, Pelaksanaan Tata Usaha Keuangan Daerah dan Penyusunan Perhitungan Anggaran dan Belanja Daerah. Keberadaan Kepmendagri ini adalah sebagai aturan pelaksanaan dari Peraturan Pemerintah Nomor 105 tahun 2000. Dengan adanya Kepmendagri Nomor 29 Tahun 2002 daerah-daerah diwajibkan untuk menyusun APBD dan membuat Sistem Akuntansi Keuangan Daerahnya dengan mengacu kepada Kepmendagri Nomor 29 Tahun 2002. Dalam pelaksanaannya, Kepmendagri Nomor 29 Tahun 2002 ini setengah dipaksakan bagi Pemerintah Daerah untuk menjadi acuan utama dalam pengelolaan keuangan. Bahkan daerah-daerah diwajibkan untuk menyusun APBD dan membuat Sistem Akuntansi Keùangan Daerahnya dengan mengacu kepada Kepmendagri Nomor 29 Tahun 2002 ini. Suatu pemaksaan yang justru menggambarkan kelemahannya. Selain membingungkan, Kepmendagri No. 29/2002 tidak memiliki landasan konsepsional yang kuat sehingga tidak memiliki konsistensi karena sering berubah-ubah dalam sosialisasi melalui training dan pelatihan-pelatihannya. Hal ini wajar karena Kepmendagri No. 29/2002 ini lahir berkat adanya ayat sisipan (colongan) dalam PP 105/2000. Dengan ayat ini, maka dibuatlah proyek-proyek besar berskala nasional yang banyak menyerap dan menghasilkan dana, baik dari dana pusat maupun dari daerah-daerah. (www.keuangan-daerah.blogspot.com dikutip tanggal 03 Maret 2011)

Fakta yang termuat dalam Ikhtisar Hasil Pemeriksaan Semester I BPK tahun 2010 ditemukan sebanyak 1.256 kasus kelemahan sistem akuntansi dan pelaporan. Dari 1.256 kasus tersebut dapat diuraikan bahwa; (1) Sebanyak 579 kasus pencatatan tidak/belum dilakukan atau tidak akurat; (2) Sebanyak 439 kasus proses penyusunan laporan tidak sesuai dengan ketentuan; (3) Sebanyak 25 kasus entitas terlambat menyampaikan laporan; (4) Sebanyak 186 kasus sistem informasi akuntansi dan pelaporan tidak memadai; dan (5) Sebanyak 27 kasus sistem informasi akuntansi dan pelaporan belum didukung SDM yang memadai.

Keberadaan sebuah sistem akuntansi menjadi sangat penting karena fungsinya dalam menentukan kualitas informasi pada laporan keuangan. Indra Bastian (2007: 4) mengungkapkan bahwa jika belum memahami sistem akuntansi, maka belum memahami penyusunan laporan keuangan, karena akuntansi pada dasarnya merupakan sistem pengolahan informasi yang menghasilkan keluaran berupa informasi akuntansi atau laporan keuangan. Sistem akuntansi memberikan pengetahuan tentang pengolahan informasi akuntansi sejak data direkam dalam dokumen sampai dengan laporan yang dihasilkan.

Sementara itu, Mardiasmo (2004: 34) mengungkapkan bahwa untuk dapat menghasilkan laporan keuangan yang relevan, handal, dan dapat dipercaya, pemerintah daerah harus memiliki sistem akuntansi yang handal. Sistem akuntansi yang lemah menyebabkan pengendalian intern lemah dan pada akhirnya laporan keuangan yang dihasilkan juga kurang handal dan kurang relevan untuk pembuatan keputusan. Saat ini sistem akuntansi yang dimiliki pemerintah daerah rata-rata masih lemah.

Badan Pengawasan Keuangan dan Pembangunan (BPKP) mendefinisikan akuntabilitas sebagai perwujudan kewajiban seseorang atau unit organisasi untuk mempertanggungjawabkan pengelolaan sumber daya dan pelaksanaan kebijakan yang dipercayakan kepadanya dalam rangka pencapaian tujuan yang telah ditetapkan melalui media pertanggungjawaban berupa laporan akuntabilitas kinerja secara periodik. 
Hasil pemeriksaan BPK RI atas Laporan Keuangan Pemerintah Kota Bandung tahun 2009 menunjukkan temuan duplikasi kegiatan antara perjalanan dinas dengan kegiatan lainnya (rapat) pada Sekretariat DPRD Kota Bandung Tahun Anggaran 2008 sebesar Rp 75.140.000,00. Temuan ini diindikasikan dikarenakan pegawai tidak memahami tujuan yang hendak dicapai dari prinsip pengeluaran belanja daerah yang termuat dalam Permendagri Nomor 13 Tahun 2006 Pasal 122 ayat 10 yaitu, prinsip hemat, tidak mewah, efektif, efisien dan sesuai dengan peraturan perundangan. Selain itu, pimpinan dalam hal ini Sekretaris DPRD Kota Bandung sebagai Pengguna Anggaran dinilai telah lalai dalam melaksanakan pengawasan dan pengendalian.

Badan Pemeriksa Keuangan menemukan 166 temuan pemeriksaan senilai Rp 2,62 triliun dalam laporan keuangan tahun 2008 di sembilan kabupaten dan kota di Jawa Barat. Kesembilan daerah itu adalah Kota Bandung, Kota Tasikmalaya, Kota Bekasi, Kota Cirebon, Kota Cimahi, Kabupaten Cirebon, Kabupaten Indramayu, Kabupaten Subang, dan Kabupaten Bandung Barat. Temuan masalah itu terdiri dari kerugian daerah, potensi kerugian daerah, kekurangan penerimaan, masalah administrasi, sistem pengendalian intern, dan kinerja. Pendapat disclaimer diberikan kepada Kabupaten Bandung Barat karena Kabupaten Bandung Barat bisa dikatakan baru terbentuk, sistem keuangannya belum berjalan baik, dan sedang terus dibenahi. Dibanding delapan daerah lainnya, nilai nominal temuan laporan keuangan Kota Bandung adalah yang terbesar, yakni sekitar Rp 1,11 triliun atau hampir 50 persen dari total nilai temuan, Rp 2,62 triliun. (Tempo Interaktif, 29 Oktober 2009)

Hasil temuan BPK RI dalam pemeriksaan Laporan Keuangan Pemerintah Kabupaten Ciamis Tahun 2009 di antaranya menyangkut kepatuhan terhadap peraturan perundangan dan lima terkait dengan Sistem Pengendalian Intern. Salah satu temuannya adalah aset tetap untuk peralatan dan mesin kelompok alat lainnya sebesar Rp 99.045.309.151,00 pada Dinas Kesehatan, Dinas Pendidikan dan RSUD tidak dapat ditelusuri keberadaannya. Selain itu, penyajian akun investasi non permanen - Dana bergulir pada neraca per 31 Desember 2009 senilai Rp 4.683.141.000,00 tidak menunjukkan keadaan yang sebenarnya. (Pikiran Rakyat, 24 Agustus 2010). Sedangkan opini BPK yang diberikan atas laporan keuangan pemerintah daerah di Wilayah IV Provinsi Jawa Barat adalah sebagai berikut:

Tabel 1. Opini BPK atas Laporan Keuangan Pemda se-Priangan

\begin{tabular}{|c|c|c|c|c|}
\hline No. & Entitas Pemerintah Daerah & Opini Tahun 2007 & Opini Tahun 2008 & Opini Tahun 2009 \\
\hline 1 & Kab. Bandung & $\begin{array}{ll}\text { Wajar } & \text { Dengan } \\
\text { Pengecualian }\end{array}$ & $\begin{array}{ll}\begin{array}{l}\text { Wajar } \\
\text { Pengecualian }\end{array} & \text { Dengan } \\
\end{array}$ & $\begin{array}{ll}\text { Wajar } & \text { Dengan } \\
\text { Pengecualian } & \\
\end{array}$ \\
\hline 2 & Kab. Bandung Barat & - & $\begin{array}{l}\text { Tidak Memberikan } \\
\text { Pendapat }\end{array}$ & $\begin{array}{l}\text { Tidak Memberikan } \\
\text { Pendapat }\end{array}$ \\
\hline 3 & Kab. Ciamis & $\begin{array}{ll}\text { Wajar } & \text { Dengan } \\
\text { Pengecualian } & \\
\end{array}$ & $\begin{array}{ll}\text { Wajar } & \text { Dengan } \\
\text { Pengecualian }\end{array}$ & $\begin{array}{ll}\text { Wajar } & \text { Dengan } \\
\text { Pengecualian } & \\
\end{array}$ \\
\hline 4 & Kab. Garut & $\begin{array}{l}\text { Tidak Memberikan } \\
\text { Pendapat }\end{array}$ & $\begin{array}{ll}\begin{array}{l}\text { Wajar } \\
\text { Pengecualian }\end{array} & \text { Dengan } \\
\end{array}$ & $\begin{array}{ll}\text { Wajar } & \text { Dengan } \\
\text { Pengecualian } & \\
\end{array}$ \\
\hline 5 & Kab. Sumedang & $\begin{array}{ll}\text { Wajar } & \text { Dengan } \\
\text { Pengecualian } & \\
\end{array}$ & $\begin{array}{ll}\text { Wajar } & \text { Dengan } \\
\text { Pengecualian }\end{array}$ & $\begin{array}{ll}\text { Wajar } & \text { Dengan } \\
\text { Pengecualian } & \\
\end{array}$ \\
\hline 6 & Kab. Tasikmalaya & $\begin{array}{ll}\text { Wajar } & \text { Dengan } \\
\text { Pengecualian } & \\
\end{array}$ & $\begin{array}{ll}\begin{array}{l}\text { Wajar } \\
\text { Pengecualian }\end{array} & \text { Dengan } \\
\end{array}$ & $\begin{array}{ll}\text { Wajar } & \text { Dengan } \\
\text { Pengecualian }\end{array}$ \\
\hline 7 & Kota Bandung & $\begin{array}{ll}\text { Wajar } & \text { Dengan } \\
\text { Pengecualian } & \\
\end{array}$ & $\begin{array}{ll}\text { Wajar } \\
\text { Pengecualian }\end{array}$ & $\begin{array}{l}\text { Tidak Memberikan } \\
\text { Pendapat }\end{array}$ \\
\hline 8 & Kota Banjar & $\begin{array}{ll}\text { Wajar } & \text { Tanpa } \\
\text { Pengecualian } & \\
\end{array}$ & $\begin{array}{ll}\text { Wajar } \\
\text { Pengecualian }\end{array}$ & $\begin{array}{ll}\text { Wajar } & \text { Dengan } \\
\text { Pengecualian }\end{array}$ \\
\hline 9 & Kota Cimahi & $\begin{array}{ll}\text { Wajar } & \text { Dengan } \\
\text { Pengecualian } & \\
\end{array}$ & $\begin{array}{ll}\begin{array}{l}\text { Wajar } \\
\text { Pengecualian }\end{array} & \text { Dengan } \\
\end{array}$ & $\begin{array}{ll}\text { Wajar } & \text { Dengan } \\
\text { Pengecualian }\end{array}$ \\
\hline 10 & Kota Tasikmalaya & $\begin{array}{l}\text { Tidak Memberikan } \\
\text { Pendapat }\end{array}$ & $\begin{array}{ll}\text { Wajar } \\
\text { Pengecualian }\end{array}$ & $\begin{array}{ll}\text { Wajar } & \text { Dengan } \\
\text { Pengecualian }\end{array}$ \\
\hline
\end{tabular}

Sumber: IHPS Semester I BPK 2010. Data diolah.

Fakta tersebut di atas merupakan suatu indikasi bahwa terdapat masalah pada pengelolaan dan kewajaran penyajian laporan keuangannya sehingga mengakibatkan tidak tercapainya opini terbaik yaitu Wajar Tanpa Pengecualian (WTP). Keadaan ini sangat ironis mengingat laporan keuangan pemerintah daerah merupakan bentuk pertanggungjawaban dana publik yang dikelola oleh pemerintah daerah.

Kasubag Hukum dan Humas BPK Jawa Barat Nurina Hijiani mengungkapkan bahwa, penyajian aset Kota Bandung tidak didukung rincian daftar aset maupun dokumen berupa daftar inventarisasi dan penilaian aset tersebut. Jika pun data inventaris dimiliki, data tersebut sudah tidak mutakhir dan tidak valid. Karena mutasi barang antar SKPD tidak diikuti dengan mutasi 
pencatatan. Selain itu, penyajian piutang dan utang tidak didukung dengan rincian daftar debitur/kreditur maupun dokumen sumber bukti keterjadian piutang/utang tersebut. Penyajian persediaan tidak didukung dengan rincian daftar persediaan dan tidak dilengkapi dengan berita acara stock opname pada tanggal neraca. Selain itu, penyertaan modal pemerintah kepada perusahaan daerah di atas $20 \%$ tidak disajikan dengan metoda equitas sebagaimana dinyatakan dalam standar akuntansi pemerintahan. Penyajian dan pengungkapan dana bergulir pada masyarakat tidak disajikan sesuai nilai bersih yang dapat direalisasikan sebagaimana dinyatakan dalan standar akuntasi pemerintahan. Selain itu, hal lainnya adalah penyajian aset tidak didukung rincian daftar aset maupun dokumen berupa daftar inventarisasi dan penilaian aset tersebut. (BPK, 03 Maret 2011)

\section{Rumusan Masalah}

1. Apakah Sistem Akuntansi Keuangan Daerah berpengaruh terhadap Akuntabilitas Keuangan Daerah.

2. Apakah Sistem Akuntansi Keuangan Daerah berpengaruh terhadap Akuntabilitas Keuangan Daerah dengan Kualitas Laporan Keuangan sebagai Variabel Intervening.

\section{Kerangka Pemikiran}

Dalam menjalankan suatu entitas, baik itu entitas sektor publik maupun entitas swasta, diperlukan sistem akuntansi yang berkualitas untuk menyajikan laporan keuangan dengan kualitas informasi akuntansi yang sesuai dengan karakteristik kualitatif yang telah ditentukan oleh standar akuntansi. Laporan keuangan pemerintah sebagai salah satu bentuk pertanggungjawaban pemerintah daerah dalam pengelolaan dana publik diharapkan memiliki kualitas informasi yang baik dan sesuai dengan standar.

Definisi Akuntansi Keuangan Daerah menurut Abdul Halim dalam Abdul Hafiz Tanjung (2009: 35) adalah proses pengidentifikasian, pengukuran, pencatatan, dan pelaporan transaksi ekonomi (keuangan) dari entitas pemerintahan daerah (kabupaten, kota, atau provinsi) yang dijadikan informasi berupa pelaporan yang berguna dalam pengambilan keputusan ekonomi oleh pihak-pihak internal dan eksternal pemerintah daerah yang memerlukan. Dalam Permendagri Nomor 59 Tahun 2007 tentang Pedoman Pengelolaan Keuangan Negara, sistem akuntansikeuangan daerah didefinisikan sebagai serangkaian prosedur mulai dari proses pengumpulan data, pencatatan, pengikhtisaran, sampai dengan pelaporan keuangan dalam rangka pertanggungjawaban pelaksanaan APBD yang dapat dilakukan secara manual atau menggunakan aplikasi komputer.

Menurut La Midjan dan Azhar Susanto (2001: 37) salah satu tujuan utama dari sistem akuntansi adalah untuk meningkatkan kualitas informasi. Informasi yang tepat guna (relevance), lengkap dan terpercaya (akurat). Dengan kata lain sistem akuntansi harus dengan cepat dan tepat dapat memberikan informasi yang diperlukan secara lengkap.

Sistem akuntansi yang dirancang dan dijalankan dengan baik akan menjamin dilakukannya prinsip stewardship dan accountability dengan baik pula. Pemerintah atau unit kerja pemerintah perlu memiliki sistem akuntansi yang tidak saja berfungsi sebagai alat pengendalian transaksi keuangan, akan tetapi sistem akuntansi tersebut hendaknya mendukung pencapaian tujuan organisasi. (Mardiasmo, 2002: 37)

Penyusunan laporan keuangan pemerintah daerah yang bertujuan sebagai salah satu bentuk pertanggungjawaban (accountability) pemerintah daerah yang memenuhi karakteristik kualitatif sesuai dengan kriteria yang ditentukan dalam PP Nomor 71 Tahun 2010 di meliputi Relevan, Andal, Dapat Dibandingkan, dan Dapat Dipahami ditentukan oleh sistem akuntansi yang dirancang dan dijalankan. Sistem akuntansi yang dirancang dan dijalankan dengan baik akan menjamin dilakukannya prinsip stewardship dan accountability. Implementasi sistem akuntansi keuangan daerah yang baik dapat menyajikan laporan keuangan pemerintah daerah dengan informasi yang tepat guna (relevance), lengkap dan terpercaya (akurat) sehingga karakteristik kualitatif laporan keuangan dapat terpenuhi.

\section{Metode Penelitian}

Berdasarkan tujuan yang ingin dicapai, maka penelitian ini menggunakan desain kausal. Sementara sumber data yang digunakan untuk penelitian ini adalah data primer. Data primer 
diperoleh melalui penelitian lapangan yaitu dengan mengadakan observasi, wawancara, memberikan daftar pertanyaan (kuesioner) serta mengumpulkan catatan dan dokumen yang berhubungan dengan objek yang sedang diteliti. Kuesioner dalam penelitian disusun dengan Skala Likert dengan Skala Data Ordinal. Dalam penelitian ini seluruh anggota populasi dikenai penelitian, maka penulis tidak menggunakan teknik sampling. Penulis menggunakan sensus dalam penelitian ini. Hal ini sesuai dengan yang diungkapkan oleh Sudjana (1996: 6) bahwa sensus dilakukan jika setiap anggota tiada terkecuali yang ada dalam sebuah populasi dikenai penelitian. Selain itu, Nur Indriantoro dan Bambang Supomo (2002: 117) mengungkapkan bahwa sensus perlu dipertimbangkan untuk dilakukan jika elemem-elemen populasi relatif sedikit. teknis analisis data dalam penelitian ini menggunakan Uji Validitas dan Reliabilitas Data, Transformasi Data dengan menggunakan Metode Successive Interval (MSI), Uji Asumsi Klasik, Koefisien Determinasi, dan Analisis Jalur (Path Analysis).

\section{Hasil Penelitian dan Pembahasan}

Untuk pengaruh Sistem Akuntansi Keuangan Daerah terhadap Kualitas Laporan Keuangan diperoleh koefisien determinasi sebesar $0.1 \%$, sedangkan sisanya sebesar $99.9 \%$ adalah pengaruh faktor lain. Sehingga dengan tingkat kepercayaan 95\% dapat disimpulkan bahwa Sistem Akuntansi Keuangan Daerah tidak memiliki pengaruh yang signifikan terhadap Kualitas Laporan Keuangan. Selanjutnya untuk hasil pengujian secara langsung yang meliputi pengujian pengaruh Sistem Akuntansi Keuangan Daerah dan Kualitas Laporan Keuangan terhadap Akuntabilitas Keuangan Daerah. besarnya pengaruh langsung dari Sistem Akuntansi Keuangan Daerah terhadap Akuntabilitas Keuangan Daerah adalah sebesar 18,4\%, sedangkan pengaruh Kualitas Laporan Keuangan terhadap Akuntabilitas Keuangan Daerah adalah sebesar 12,5\%. Sehingga dengan tingkat kepercayaan 95\% dapat disimpulkan bahwa masing-masing variabel Sistem Akuntansi Keuangan Daerah dan Kualitas Laporan Keuangan tidak memiliki pengaruh yang signifikan terhadap Akuntabilitas Keuangan Daerah. Sedangkan untuk hasil pengujian pengaruh Sistem Akuntansi Keuangan Daerah terhadap Akuntabilitas Keuangan Daerah dengan Kualitas Laporan Keuangan sebagai variabel intervening yang dilakukan dengan Uji $\mathrm{F}$ diperoleh hasil besarnya kontribusi pengaruh dari Sistem Akuntansi Keuangan Daerah terhadap Akuntabilitas Keuangan Daerah dengan Kualitas Laporan Keuangan sebagai Variabel Intervening adalah sebesar 31,7\%, sedangkan sisanya sebesar $68,3 \%$ merupakan pengaruh faktor lain diluar kedua variabel tersebut. Sehingga dengan tingkat kepercayaan 95\% dapat disimpulkan Sistem Akuntansi Keuangan Daerah dengan Kualitas Laporan Keuangan sebagai Variabel Intervening tidak memiliki pengaruh yang signifikan terhadap Akuntabilitas Keuangan Daerah.

\section{Simpulan}

1. Sistem Akuntansi Keuangan Daerah tidak memiliki pengaruh yang signifikan terhadap Akuntabilitas Keuangan Daerah. Sistem Akuntansi Pemerintah Daerah memiliki kontribusi pengaruh sebesar 18,4\%, sehingga dengan tingkat kepercayaan $95 \%$ dapat disimpulkan bahwa Sistem Akuntansi Keuangan Daerah tidak memiliki pengaruh yang signifikan terhadap Akuntabilitas Keuangan Daerah.

2. Sistem Akuntansi Keuangan Daerah dengan Kualitas Laporan Keuangan sebagai variabel intervening tidak memiliki pengaruh yang signifikan terhadap Akuntabilitas Keuangan Daerah. Sistem Akuntansi Pemerintah Daerah dengan Kualitas Laporan Keuangan sebagai Variabel Intervening memiliki kontribusi pengaruh sebesar 31,7\%, sehingga dengan tingkat kepercayaan 95\% dapat disimpulkan bahwa Sistem Akuntansi Keuangan Daerah dengan Kualitas Laporan Keuangan sebagai Variabel Intervening tidak memiliki pengaruh yang signifikan terhadap Akuntabilitas Keuangan Daerah.

\section{Saran}

1. Aparatur pemerintah daerah di Wilayah IV Provinsi Jawa Barat khususnya untuk fungsi akuntansi masih perlu untuk untuk meningkatkan pemahaman dan penguasaan Sistem Akuntansi Keuangan Daerah dalam rangka Pengelolaan Keuangan Daerah. Pendidikan dan pelatihan perlu dilakukan terutama dengan sangat dinamisnya perkembangan regulasi peraturan di lingkungan sektor pemerintahan. Pendidikan dan pelatihan ini diharapkan 
menjadi media yang efektif agar aparatur terkait mengetahui prosedur akuntansi terbaru baik itu tentang pengelolaan keuangan daerah maupun standar akuntansi pemerintahan. Di samping itu, berdasarkan hasil penelitian yang menunjukkan bahwa kualitas laporan keuangan memiliki peran dalam mewujudkan akuntabilitas keuangan daerah sehingga aparatur fungsi akuntansi di lingkungan pemerintah daerah dituntut untuk menyusun serta menyajikan laporan keuangan yang memenuhi karakteristik kualitatif laporan keuangan sebagaimana yang telah ditetapkan dalam Peraturan Pemerintah Nomor 71 Tahun 2010.

2. Inspektorat sebagai lembaga yang memiliki wewenang untuk melakukan review dan menilai kualitas laporan keuangan secara intern untuk pemerintah daerah harus berusaha mendorong pemerintah daerah untuk mewujudkan tata kelola yang baik atas pengelolaan dan tanggung jawwab keuangan daerah dengan memberikan pengarahan dan pengawasan dalam rangka perbaikan atas hasil pemeriksaan dan temuan yang diberikan oleh Badan Pemeriksa Keuangan. Sehingga dengan hal tersebut, pemerintah daerah dapat memenuhi prinsip tata kelola keuangan daerah yang baik guna meningkatkan tingkat kewajaran informasi yang disajikan dalam laporan keuangan pemerintah daerah.

3. Kepala Daerah agar menyusun Peraturan Gubernur/Peraturan Bupati/Peraturan Walikota yang mengatur petunjuk teknis tentang pengelolaan keuangan daerah yang mengacu pada Permendagri Nomor 59 Tahun 2007 dan Peraturan Pemerintah Nomor 71 Tahun 2010. Hal ini dilakukan agar aparatur fungsi akuntansi memiliki payung hukum yang lebih jelas dalam pelaksanaan sistem akuntansi keuangan daerah.

4. Bagi peneliti selanjutnya yang tertarik untuk melakukan penelitian sejenis, penulis menyarankan sebaiknya menambah variabel penelitian dengan efektifitas penerapan standar akuntansi pemerintahan dan kualitas sumber daya manusia hal ini karena penerapan standar akuntansi pemerintahan dan kualitas sumber daya fungsi akuntansi juga memiliki peran yang sangat penting dalam menentukan kualitas laporan keuangan sebagai salah satu bentuk pertanggungjawaban (accountability) pemerintah daerah. Standar akuntansi pemerintah terkait dengan metode akuntansi, kebijakan akuntansi, serta meliputi pengukuran dan penilaian merupakan persyaratan bagi pemerintah yang mempunyai kekuatan hukum, sehingga pemerintah wajib menerapkannya dalam upaya meningkatkan kualitas laporan keuangan. Selain itu, perlu juga dilakukan penelitian dengan sampel yang lebih banyak dan tidak terbatas pada Dinas, Kantor dan Badan Pengelolaan Keuangan Daerah saja, namun diperluas untuk seluruh Dinas di Pemerintahan Kabupaten maupun Pemerintahan Kota. Perlu dilakukan pengembangan instrumen penelitian yang disesuaikan dengan kondisi dan lingkungan dari obyek yang diteliti.

Daftar Pustaka

Abdul, Hafiz Tanjung. (2009). Akuntansi Pemerintahan Daerah: Konsep dan Aplikasi Sesuai Standar Akuntansi Pemerintahan. Bandung: ALFABETA.

Abdul, Kadir. (2003). Pengenalan Sistem Informasi. Yogyakarta: Andi.

Adrianus, Fajar. (2010). "Pengaruh Sistem Akuntansi Keuangan Daerah terhadap Kualitas Laporan Keuangan Kabupaten Bandung". Skripsi. Bandung: Universitas Pendidikan Indonesia.

Alam, S. (2004). Akuntansi SMA untuk Kelas XI. Jakarta: Esis.

Bachtiar Arif, et all. (2002). Akuntansi Pemerintahan. Jakarta: Salemba Empat.

Badan Pemeriksa Keuangan. (2010). Ikhtisar Hasil Pemeriksaan Semester (IHPS) I Tahun 2010. Jakarta.

Badan Pemeriksa Keuangan. (2008). Laporan Hasil Pemeriksaan Atas Kepatuhan terhadap Peraturan Perundang-undangan Dalam Kerangka Pemeriksaan Laporan Keuangan Pemerintah Kota Bandung Tahun Anggaran 200X. Bandung.

Badan Pengawasan Keuangan dan Pembangunan. (2007). Modul Akuntabilitas Instansi Pemerintah Edisi Kelima. Pusat Pendidikan Dan Pelatihan Pengawasan Badan Pengawasan Keuangan Dan Pembangunan.

Budi, S. Poernomo. (2009). Obligasi Daerah Alternatif Investasi Masyarakat dan Sumber Bagi Pemerintah Daerah. Bandung: Alfabeta. 
Chandra, Mulyana. (2010). "Pengaruh Pengetahuan Anggota Legislatif Daerah Tentang Anggaran Terhadap Pengawasan Anggaran Pendapatan dan Belanja Daerah Dengan Variabel Moderating Akuntabilitas dan Partisipasi Masyarakat (Penelitian Pada DPRD Kota Tasikmalaya)". Skripsi. Purwokerto: Universitas Jenderal Soedirman.

Deddi Nordiawan. (2007). Akuntansi Sektor Publik. Jakarta: Salemba Empat.

Dermawan, Wibisono. (2002). Riset Bisnis: Panduan Praktis Bagi Praktisi dan Akademisi. Jakarta: PT. Gramedia Pustaka Utama.

Hasil Temuan BPK Dalam Pemeriksaan Laporan Keuangan Pemerintah Kabupaten Ciamis Tahun 2009. [Online]. [Tersedia]: http://www.pikiran-rakyat.com/node/120619 [03 Maret

Husein, Umar. (2003). Metode Riset Akuntansi Terapan. Jakarta: Ghalia Indonesia.

Husein, Umar. (2008). Desain Penelitian Akuntansi Keperilakuan. Jakarta: RajaGrafindo Persada.

Indra, Bastian. (2006). Akuntansi Sektor Publik: Suatu Pengantar. Jakarta: Erlangga.

Indra, Bastian. (2007). Sistem Akuntansi Sektor Publik Edisi 2. Jakarta: Salemba Empat.

Irman, Firmansyah. (2008). "Peran Sistem Akuntansi Keuangan Daerah dalam Mewujudkan Tranparansi dan Akuntabilitas Keuangan Pemerintah Provinsi Jawa Barat". Skripsi. Bandung: Fakultas Ekonomi Universitas Widyatama.

La Midjan dan Azhar Susanto. (2001). Sistem Informasi Akuntansi 1: Pendekatan Manual Praktika Penyusunan Metode dan Prosedur. Bandung: Lingga Jaya.

Lyna Latifah dan Arifin Sabeni. (2006). "Faktor Keprilakuan Organisasi dalam Implementasi Sistem Akuntansi Keuangan Daerah (Studi Empiris pada Pemerintah Kabupaten dan Kota di Jawa Tengah dan Daerah Istimewa Yogyakarta)". Jurnal Ilmiah. Simposium
Nasional Akuntansi X.

Mardiasmo. (2001). Akuntansi Sektor Publik. Yogyakarta: ANDI.

Mardiasmo. (2004). Otonomi dan Manajemen Keuangan Daerah. Yogyakarta: ANDI.

Mira, Tania. (2009). "Pengaruh Sistem Akuntansi Keuangan Daerah Terhadap Akuntabilitas Laporan Keuangan Daerah Pemerintah Kota Bandung". Skripsi. Bandung: Fakultas
Ekonomi Universitas Komunikasi Indonesia.

Moh. Nazir. (2005). Metode Penelitian. Bogor: Ghalia Indonesia.

Mulyadi. (2001). Sistem Akuntansi Edisi ke-3. Jakarta: Salemba Empat.

Nur Indriantoro dan Bambang Supomo. (2002). Metodologi Penelitian Bisnis Untuk Akuntansi dan Manajemen. Yogyakarta: BPFE.

Opini Laporan Keuangan Pemerintah Kota Bandung. [Online]. [Tersedia]: http://us.bandung.detik.com/read/2010/08/13/160717/1420024/486/bpk-disclaimer-laporankeuangan-kota-bandung-2009 [03 Maret 2011]

Pelaksanaan Keputusan Menteri Dalam Negeri Tahun 2002. [Online]. [Tersedia]: http://www.keuangan-daerah.blogspot.com/ [03 Maret 2011] Peraturan Menteri Dalam Negeri Nomor 59 Tahun 2007 tentang Pedoman Pengelolaan Keuangan
Daerah.

Peraturan Pemerintah Nomor 22 Tahun 2008 tentang Wewenang Inspektorat

Peraturan Pemerintah Nomor 71 Tahun 2010 tentang Standar Akuntansi Pemerintahan.

Putri Ayu Rizqi Rengganis. (2010). "Hubungan Penerapan Enterprise Resource Planning (ERP)dengan Efektifitas Pengendalian Intern Gaji". Skripsi. Bandung: Universitas Pendidikan Indonesia.

Riduwan dan Engkos, Achmad Kuncoro. (2008). Cara Menggunakan dan Memakai Analisis Jalur (Path Analysis). Bandung: ALFABETA.

Sinaga, Timbul. (2003). "Pengaruh Ketidakstabilan Nilai Tukar Rupiah dan Kebijakan Akuntansi terhadap Kualitas Laporan Keuangan dan Keputusan Ekonomi”. Jurnal Ilmiah Akuntansi.
Vol 2 No. 1.

Siti Nurlaela dan Rahmawati. (2010). "Pengaruh Faktor Keperilakuan Organisasi Terhadap Kegunaan Sistem Akuntansi Keuangan Daerah di Subosukawonosraten". Jurnal Ilmiah. Simposium Nasional Akuntansi XIII Purwokerto.

Sudjana. (1996). Metoda Statistika Edisi ke-6. Bandung: TARSITO.

Sugiyono. (1999). Statistika untuk Penelitian. Bandung: ALFABETA. 
Temuan Pemeriksaan dalam Laporan Keuangan Tahun 2008 di Sembilan Kabupaten dan Kota di Jawa Barat. [Online]. [Tersedia]: http://www.tempointeraktif.com/hg/nusa/2009/10/29/brk,20091029-205290,id.html $[04$ Maret 2011]

Toni, Irwana. (2010). "Pengaruh Efektifitas Penerapan Standar Akuntansi Pemerintahan terhadap Kualitas Laporan Keuangan". Skripsi. Bandung: Universitas Pendidikan Indonesia.

Undang-undang Nomor 1 Tahun 2004 tentang Perbendaharaan Negara.

Undang-undang Nomor 17 Tahun 2003 tentang Keuangan Negara.

Weygandt, Jerry J., et.al. (2005). Accounting Principles $7^{\text {th }}$ Edition. John Wiley and Sons. Wijaya. (2001). Analisis Statistik dengan Program SPSS 10.0. Bandung: ALFABETA.

Wilkinson, et.all. (1997). Accounting Information System Fourth Edition. John Wiley and Sons. Zaki, Baridwan. (2004). Intermediate Accounting Edisi 8. Yogyakarta: BPFE. 